\title{
Effect of potato peel, pumpkin seed, and quinoa flours on sensory and chemical characteristics of gluten-free breads
}

\author{
Efeito das farinhas de casca de batata, semente de abóbora e \\ quinoa nas características sensoriais e químicas de pães isentos \\ de glúten
}

\author{
Gabriela Jacinto ${ }^{1}$, Anderso Stieven², Mônica Jachetti Maciel ${ }^{3}$, Claucia Fernanda Volken de Souza ${ }^{4 *}$ (D) \\ ${ }^{1}$ Universidade do Vale do Taquari (Univates), Centro de Ciências Biológicas e da Saúde, Teutônia/RS - Brasil \\ ${ }^{2}$ Universidade do Vale do Taquari (Univates), Centro de Ciências Exatas e Tecnológicas, Lajeado/RS - Brasil \\ ${ }^{3}$ Universidade do Vale do Taquari (Univates), Programa de Pós-graduação em Sistemas Ambientais Sustentáveis, \\ Lajeado/RS - Brasil \\ ${ }^{4}$ Universidade do Vale do Taquari (Univates), Programa de Pós-graduação em Biotecnologia e em Sistemas \\ Ambientais Sustentáveis, Lajeado/RS - Brasil
}

*Corresponding Author: Claucia Fernanda Volken de Souza, Universidade do Vale do Taquari (Univates),

Programa de Pós-graduação em Biotecnologia e em Sistemas Ambientais Sustentáveis, Rua Avelino Tallini, 171, sala 309, prédio 8, CEP: 95914-014, Lajeado/RS - Brasil, e-mail: claucia@univates.br

Cite as: Jacinto, G., Stieven, A., Maciel, M. J., \& Souza, C. F. V. (2020). Effect of potato peel, pumpkin seed, and quinoa flours on sensory and chemical characteristics of gluten-free breads. Brazilian Journal of Food Technology, 23, e2019169. https://doi.org/10.1590/1981-6723.16919

\begin{abstract}
Celiac disease is characterized by the body's inability to digest gluten in the small intestine, and the dietary treatment consists of avoiding foods that contain this protein. Potato peel, pumpkin seeds, and quinoa are ingredients that can be used to produce gluten-free bread. The aim of this work was to evaluate chemical and sensory characteristics of gluten-free breads consisting of the idea to compare both made with traditional ingredients and with the addition of Potato Peel Flour (PPF), Pumpkin Seed Flour (PSF), and Quinoa Flour (QF). Sensory analysis of the prepared glutenfree breads and chemical analysis of the alternative flours were performed, as well as the formulations developed. The bread formulation with traditional flours and starches that obtained the highest acceptance in the sensory evaluation was used as a base to prepare three bread formulations, with $2.5 \%, 5.0 \%$, and $7.5 \%$ of each alternative flours. Regarding the chemical analysis of the flours, carbohydrate concentrations of PPF and QF did not differ statistically. Lipid, protein, and ash levels in PSF were significantly higher than those in the other flours. Carbohydrate, ash, and lipid contents of the three formulations made with alternative flours showed no significant differences. The formulation with $5.0 \%$ of the alternative flours had higher sensory acceptance. The results showed that the alternative flours used are viable alternatives for the production of gluten-free breads, making it possible to improve the diet of part of the population with celiac disease by increasing the nutritional contents of minerals, lipids, and proteins.
\end{abstract}

Keywords: Alternative flours; Starches; Celiac disease; Gluten intolerance; Chemical analysis; Sensory acceptance. 


\section{Resumo}

A doença celíaca é caracterizada pela incapacidade do organismo de digerir o glúten no intestino delgado, e o tratamento dietético consiste em evitar alimentos que contenham essa proteína. Casca de batata, semente de abóbora e quinoa são ingredientes que podem ser usados para produzir pão sem glúten. O objetivo deste trabalho foi avaliar as características químicas e sensoriais de pães isentos de glúten adicionados de farinhas de casca de batata (FCB), semente de abóbora (FSA) e quinoa (FQ). Foram realizadas a análise sensorial dos pães preparados sem glúten e a análise química das farinhas alternativas e das formulações de pães elaboradas. A formulação do pão com farinhas e amidos tradicionais que obteve maior aceitação na avaliação sensorial foi utilizada como base para preparar as três formulações de pães com 2,5\%, 5,0\% e 7,5\% de cada uma das farinhas alternativas. Na análise química das farinhas, as concentrações de carboidratos da FCB e FQ não diferiram estatisticamente. Os níveis de lipídios, proteínas e cinzas da FSA foram significativamente maiores que os das demais farinhas. Os teores de carboidratos, cinzas e lipídios das três formulações elaboradas com as farinhas alternativas não apresentaram diferença significativa. A formulação com $5,0 \%$ das farinhas alternativas apresentou maior aceitação sensorial. Os resultados obtidos demonstram que as farinhas utilizadas são alternativas viáveis para a produção de pães sem glúten, o que torna possível melhorar a dieta da população com doença celíaca pelo aumento do teor nutricional de minerais, proteínas e lipídios.

Palavras-chave: Farinhas alternativas; Amidos; Doença celíaca; Intolerância ao glúten; Qualidade química; Aceitação sensorial.

\section{Introduction}

As defined by the National Health Surveillance Agency (NHSA), bread is made by cooking dough, which may be fermented or not, prepared with wheat flour and/or other flours combined with liquids, and it may contain other ingredients (Brasil, 2005). Bread is a popular product among Brazilians and is one of the five most consumed foods in the country among all income brackets (Souza et al., 2013).

Gluten is found in grains such as wheat, rye, and barley, in other words, ingredients often used in human diet worldwide (Ludvigsson et al., 2013). Gluten is comprised of two protein groups: glutenin and gliadin (Scheuer et al., 2011). Glutenin forms a rubbery texture when hydrated, whereas gliadin forms a more viscous mass. Due to these properties, it is difficult for baked goods production, especially breads, which are glutenfree and yet have sensory and structural characteristics similar to those containing this protein. The lack of gluten often results in a liquid batter, that is, a bread with a crumbling texture, poor color, and other quality issues. It is not easy to facilitate gas retention by using gluten-free flour because of the lack of flexibility of glutenin, and it is difficult to have the desired crumb volume as well as the appearance because it lacks the elasticity provided by gliadin (Gallagher et al., 2004; Wang et al., 2017).

Celiac disease is characterized by the body's inability to digest gluten in the small intestine. This disease affects approximately $1.4 \%$ of the global population based on serologic test results and $0.7 \%$ based on biopsy results (Singh et al., 2018). It is difficult to diagnose it accurately because the disease has similar symptoms to other pathologies. The symptoms may be classic, such as gastrointestinal symptoms, including abdominal pain, diarrhea, constipation, and bloating (Paul et al., 2013), or atypical symptoms, such as fatigue, weight loss, and bone problems, as well as silent signs, e.g. iron deficiency (Silvester \& Duerksen, 2013). The treatment is basically dietary, requiring the elimination of foods that contain gluten from the diet. As some individuals may be symptomless, the late treatment of the disease may lead to long-term complications, such as micronutrient deficiency (deficiency of calcium absorption, e.g., leading to osteoporosis) or even cancer (Hüttner \& Arendt, 2010).

Waste originated from the food industry, primarily comprised of by-products resulting from different stages of the production process, represents a major environmental problem. Much of this waste, such as bagasse, pits, seeds, and bark, is rich in fiber, proteins, minerals, and vitamins, among others. Thus, 
this waste can and should be used for human consumption, thereby reducing the environmental impact (Ziglio et al., 2007). In 2017, global pumpkin production reached 27.4 million tons (Food and Agriculture Organization, 2017), while its production in Brazil in 2006 was approximately 385 thousand tons (Instituto Brasileiro de Geografia e Estatística, 2012). According to Pumar et al. (2005), 23\% of waste from pumpkin industrial processing is comprised of peels and seeds. Regarding potato, global production reached 388 million tons in 2017, and the Brazilian production was 3.6 million tons in the same year (Food and Agriculture Organization, 2017). This production volume represents a large amount of potato peel waste, since $8 \%$ of potatoes are lost in peeling during industrial processing (Jha, 2015). Therefore, potato peels and pumpkin seeds are good examples of by-products that could be used in food production in order to reduce environmental impacts. Potato peel is rich in potassium, manganese, zinc, iron, phosphorus, niacin, vitamins B complex, antioxidant compounds, and fiber (Fernandes et al., 2008; Garmus et al., 2009; Rodríguez Amado et al., 2014; Ben Jeddou et al., 2017). According to Sá (2007), pumpkin seeds have more fiber content than beans and lentils, as well as mineral content than most traditional flours, especially refined flours.

Quinoa (Chenopodium quinoa Willd.) belongs to the Chenopodiaceae family, and it is originated from the Andes. It is grown in Argentina, Peru, Bolivia, Chile, Colombia, and Ecuador due to their climatic characteristics. However, this plant has been adapted to the Brazilian climate, and it may be grown in the Cerrado (Brazilian savannah) region. Quinoa flour has high amounts of vitamins, proteins, minerals, and the amino acid lysine, and it does not contain gluten, which makes it a nutritious option for celiac patients. In addition, quinoa protein has excellent nutritional quality, similar to milk casein, and includes a well-balanced set of necessary amino acids, making it an unusually complete plant protein source for humans. The major quinoa types commercialized are white, red, and black, with different total phenolic and total carotenoid contents (Castro et al., 2007; Gordillo-Bastidas et al., 2016).

Based on the above mentioned, the aim of this study was to determine and evaluate the chemical and sensory characteristics of gluten-free breads prepared with traditional ingredients and with the addition of Potato Peel Flour (PPF), Pumpkin Seed Four (PSF), and Quinoa Flour (QF).

\section{Material and methods}

The ingredients used in bread formulations were purchased from local businesses in the city of Teutônia, in the state of Rio Grande do Sul (RS), Brazil. Potato (Solanum tuberosum L.) peels and pumpkin (Curcubita maxima L.) seeds were donated by Degasperi Atacadista, a company located in the city of Estrela, RS, Brazil. The QF was purchased at a local supermarket in the city of Teutonia, RS, Brazil. Potato peels were washed and soaked in $200 \mathrm{mg} / \mathrm{L}$ of sodium hypochlorite solution for 10 minutes, and after that, they were spread in a thin layer on a tray and placed in a forced-air oven (Pardal, REG 60) at $70{ }^{\circ} \mathrm{C}$ for 24 hours. Then, the material was ground using a semi-industrial blender (Britânia, Multi Star) and must be passed through $0.25 \mathrm{~mm}$ mesh sieve according to Garmus et al. (2009). The pumpkin seeds were washed to remove plant tissue, cleaned in a $200 \mathrm{mg} / \mathrm{L}$ of sodium hypochlorite solution for 10 minutes, heated for approximately 90 minutes in a convection oven (Ottima, Miniconv), and then, ground and passed through $0.25 \mathrm{~mm}$ mesh sieve according to DelVechio et al. (2005).

Formulations of gluten-free breads were developed in two stages. In the first stage, breads were prepared using different amounts of the ingredients (traditional flours and starches) already used in the preparation of gluten-free breads. In the second stage, the breads were prepared using the proposed alternative flours. In the first stage, breads were prepared with the following ingredients replacing wheat flour: Rice Flour (RF), Soybean Meal (SM), Potato Starch (PS), Cornstarch (CoS), and Cassava Starch (CaS). Table 1 shows the four formulations of gluten-free breads used in this first stage. 
Table 1. Formulations of gluten-free breads prepared with traditional flours and starches.

\begin{tabular}{ccccc}
\hline & \multicolumn{3}{c}{ Formulations } \\
\cline { 2 - 5 } Ingredients & A & B & C & D \\
\hline RF $(\mathrm{g})$ & 400 & 400 & 400 & 200 \\
\hline SM $(\mathrm{g})$ & - & - & - & 200 \\
\hline PS (g) & - & - & 250 & - \\
\hline CoS (g) & - & 250 & - & 10 \\
\hline CaS (g) & 250 & - & - & 12 \\
\hline Salt (g) & 10 & 10 & 10 & 250 \\
\hline Sugar (g) & 12 & 12 & 12 & 50 \\
\hline Biological yeast (g) & 25 & 25 & 25 & 240 \\
\hline Egg (g) & 50 & 50 & 50 & 30 \\
\hline Milk (mL) & 240 & 240 & 240 & 30 \\
\hline Soybean oil (mL) & 30 & 30 & & - \\
\hline
\end{tabular}

$\mathrm{RF}=$ Rice Flour; $\mathrm{SM}=$ Soybean Meal $\mathrm{PS}=$ Potato Starch $\mathrm{CoS}=$ Cornstarch $; \mathrm{CaS}=$ Cassava Starch.

Table 2 shows the formulations of the gluten-free breads prepared in the second stage, with partial replacement of soybean meal by PPF, PSF, and QF. The amounts of these flours $(2.5,5.0$, and $7.5 \%)$ were calculated based on formulation D of Table 1, considering that the sum of RF, SM, and PS totaling $100 \%$. An amount of soybean meal equal to the amount added of PPF, PSF, and QF was removed from each of the three formulations.

Table 2. Formulations of gluten-free breads prepared with alternative flours

\begin{tabular}{cccc}
\hline \multirow{2}{*}{ Ingredients } & \multicolumn{3}{c}{ Formulations } \\
\cline { 2 - 4 } & $\mathbf{E}$ & $\mathbf{F}$ & $\mathbf{G}$ \\
\hline RF $(\mathrm{g})$ & 200 & 200 & 200 \\
\hline SM $(\mathrm{g})$ & 151.25 & 102.5 & 53.75 \\
\hline PS $(\mathrm{g})$ & 250 & 250 & 250 \\
\hline PPF $(\mathrm{g})$ & $16.25(2.5 \%)$ & $32.5(5 \%)$ & $48.75(7.5 \%)$ \\
\hline PSF $(\mathrm{g})$ & $16.25(2.5 \%)$ & $32.5(5 \%)$ & $48.75(7.5 \%)$ \\
\hline QF $(\mathrm{g})$ & $16.25(2.5 \%)$ & $32.5(5 \%)$ & $48.75(7.5 \%)$ \\
\hline Salt $(\mathrm{g})$ & 10 & 10 & 10 \\
\hline Sugar $(\mathrm{g})$ & 12 & 12 & 25 \\
\hline Biological yeast $(\mathrm{g})$ & 25 & 25 & 50 \\
\hline Egg $(\mathrm{g})$ & 50 & 50 & 240
\end{tabular}

RF = Rice Flour; $\mathrm{SM}=$ Soybean Meal; PS = Potato Starch; PPF = Potato Peel Flour; PSF = Pumpkin Seed Flour; QF = Quinoa Flour.

All gluten-free bread formulations were prepared according to the following procedures. First, the ingredients were weighed on a semi-analytical electronic scale (Marte, ALS). Next, the dry ingredients (flours, starches, salt, sugar, and lastly, yeast) were manually mixed. After that, liquid ingredients (eggs, milk, and soybean oil) were slowly incorporated into this mixture. Next, the dough was homogenized in a mixer (Britânia, Multi Star) at speed 2 (75 rpm) for 10 minutes. Afterwards, the dough was transferred to a greased pan and baked in a gas oven (Continental, Caprice) for 30 minutes at $190{ }^{\circ} \mathrm{C}$. After baking, the breads were left to cool in an open and non-ventilated environment, and then, they were sliced and packaged in 
polyethylene plastic bags until the time of the chemical and sensory analyses, which did not exceed 24 hours. Figure 1 shows the flow chart of bread preparation.

\title{
Weighing of ingredients
}<smiles>C[14CH]</smiles>

\section{Mixture of dry ingredients}<smiles>C1C[Al]1</smiles>

\section{Addition of liquid ingredients}

\author{
$\downarrow$ \\ Dough homogenization<smiles>C[14CH2]</smiles> \\ Molding of dough \\ $\downarrow$ \\ Baking of dough<smiles>C[14CH2]</smiles> \\ Cooling of bread<smiles>C[Al]</smiles>

\section{Wrapping of bread}

Figure 1. Flow chart of bread preparation.

The chemical compositions of the alternative flours (PPF, PSF, and QF) and of gluten-free bread formulations were determined (within 24 hours of preparation of the breads) by the following procedures: moisture, oven drying to constant weight at $105{ }^{\circ} \mathrm{C}$; ash, incineration at $550{ }^{\circ} \mathrm{C}$; lipids, direct solvent extraction method (Soxhlet method); and protein, determination of the total nitrogen content by the Kjeldahl method and then conversion to crude protein using a factor of 6.25, as recommended by Instituto Adolfo Lutz (Instituto Adolfo Lutz, 2005). Total carbohydrate content was determined by the difference in percentage subtracting the total sum of the values found for the above-mentioned components. All analyses were performed in triplicates.

All tasters in the study signed an informed consent form, according to Resolution 196/96 of the Ministry of Health (MS) (Brasil, 1996) approved by the Research Ethics Committee of Universidade do Vale do Taquari (Taquari Valley University; Univates) under registration No. 043/10. Sensory analysis of breads was 
carried out at the Sensory Analysis Laboratory of Univates, in the city of Lajeado (RS), in individual booths under white light and at room temperature, with the samples arranged in white porcelain saucers and served on stainless steel trays. The samples (standardized to approximately $10 \mathrm{~g}$ ) were coded with random 3-digit numbers and provided to the tasters in a balanced and randomized manner. Along with the samples, room temperature water was provided for cleansing the palate, and a form containing a structured 9-point hedonic scale, ranging from 1, "dislike extremely", to 9, "like extremely", was also provided. Sensory analyses of breads were performed according to Teixeira et al. (1987). Sensory analysis, using the sensory acceptance test, was performed by 53 untrained tasters recruited among Univates students ( 13 men and 40 women), between 19 and 45 years old, who evaluated their preference in terms of the following attributes: appearance, aroma, flavor, texture, and overall impression of the product. To determine product acceptability, the relative frequency of the scores assigned by the tasters in the evaluation of the overall impression of the product and the acceptability index of the bread samples were calculated according to Dessimoni-Pinto et al. (2010) and Peuckert et al. (2010).

The results of the chemical characterization of alternative flours and the sensory and chemical analyses of breads were evaluated using an Analysis of Variance (ANOVA), and the significance of the models was evaluated using the F-test. For significant models, means were compared using Tukey's test at a 5\% level of significance using Statistica, version 7.0.

\section{Results and discussion}

Table 3 shows the results of the chemical analysis of the alternative flours used, namely pumpkin seed, potato peel, and quinoa.

Table 3. Chemical compositions of the alternative flours used

\begin{tabular}{cccc}
\hline \multirow{2}{*}{ Chemical composition (\%) } & \multicolumn{3}{c}{ Flours } \\
\cline { 2 - 4 } & PPF & PSF & QF \\
\hline Carbohydrates & $85.8 \pm 1.2^{\mathrm{a}}$ & $58.1 \pm 0.8^{\mathrm{b}}$ & $81.5 \pm 1.0^{\mathrm{a}}$ \\
\hline Ashes & $3.8 \pm 0.1^{\mathrm{b}}$ & $5.2 \pm 0.3^{\mathrm{a}}$ & $2.0 \pm 0.2^{\mathrm{c}}$ \\
\hline Lipids & $1.7 \pm 0.0^{\mathrm{c}}$ & $29.5 \pm 1.3^{\mathrm{a}}$ & $6.7 \pm 0.4^{\mathrm{b}}$ \\
\hline Proteins & $1.4 \pm 0.0^{\mathrm{c}}$ & $5.7 \pm 0.2^{\mathrm{a}}$ & $2.1 \pm 0.1^{\mathrm{b}}$ \\
\hline Moisture & $7.2 \pm 0.3^{\mathrm{b}}$ & $3.0 \pm 0.3^{\mathrm{c}}$ & $7.7 \pm 0.4^{\mathrm{a}}$ \\
\hline
\end{tabular}

$\mathrm{PPF}=$ Potato Peel Flour; PSF $=$ Pumpkin Seed Flour; QF = Quinoa Flour. Results are expressed in wet basis. Means with different letters in the same row are significantly different from each other $(p \leq 0.05)$ according to Tukey's test.

Carbohydrate levels in PPF and QF did not differ statistically $(p \geq 0.05)$ and were significantly higher $(p \leq 0.05)$ than those in PSF. However, concentrations of mineral salts (ashes), lipids, and proteins in PSF were significantly higher $(p \leq 0.05)$ than those in the other flours. Moisture contents in all flours were in accordance with the maximum value established by NHSA (Brasil, 2005), $15 \%$ (g/100 g). Garmus et al. (2009) analyzed PPF used for preparing cookies and found higher ash (7.3\%), lipid (2.5\%) and protein concentrations (2.5\%). Fernandes et al. (2008), who analyzed the use of PPF to make breads, obtained lipid content (1.61\%) similar to the present study, while the levels of ash $(2.22 \%)$ and protein $(5.56 \%)$ were lower and higher, respectively, than the results obtained here. However, according to these same authors, these differences may result from several factors, such as cultivar, maturation, soil, climate, storage conditions, and potato peeling process. As for the chemical composition of PSF (Table 3), the results obtained in this study differed from the protein content found by Pumar et al. (2008). These authors determined the chemical characteristics of the PSF used to evaluate the physiological effect in the intestinal tract of newly weaned male Wistar rats and found values of 28.37, 4.27, and 32.96\% for protein, ash, and lipid contents, respectively. The PSF compositions may differ due to soil composition, regional climate, cultivar, and flour processing as well as storage methods. Comparing chemical characteristics of QF (Table 3) with those found by Thejasri et al. (2017), who used quinoa and corn flours to produce cookies, the ash content (1.13\%) found by 
these authors was lower than that of the present study, as well the carbohydrate level (51.16\%); however, lipid (24.24\%) and protein (9.10\%) contents were higher. Lopes et al. (2009), by studying QF use, nutritional composition, and antinutritional composition, obtained $3.49 \%$ of ashes, $5.12 \%$ of lipids, and $11.52 \%$ of proteins. These differences in the chemical composition of QF are probably due to the type of flour used and to the methods used for chemical analysis.

Table 4 shows the chemical characteristics of breads made from traditional flours and starches.

Table 4. Chemical compositions of gluten-free breads made from traditional flours and starches.

\begin{tabular}{ccccc}
\hline \multirow{2}{*}{ Chemical composition (\%) } & \multicolumn{4}{c}{ Formulations } \\
\cline { 2 - 5 } & $\mathbf{A}$ & $\mathbf{B}$ & $\mathbf{C}$ & $\mathbf{D}$ \\
\hline Carbohydrates & $28.3 \pm 1.0^{\mathrm{b}}$ & $24.6 \pm 1.0^{\mathrm{c}}$ & $31.9 \pm 1.9^{\mathrm{a}}$ & $24.3 \pm 0.9^{\mathrm{c}}$ \\
\hline Ashes & $0.6 \pm 0.0^{\mathrm{c}}$ & $1.2 \pm 0.1^{\mathrm{b}}$ & $0.8 \pm 0.0^{\mathrm{bc}}$ & $1.4 \pm 0.1^{\mathrm{a}}$ \\
\hline Lipids & $2.6 \pm 0.3^{\mathrm{bc}}$ & $4.2 \pm 0.4^{\mathrm{b}}$ & $1.8 \pm 0.1^{\mathrm{c}}$ & $6.3 \pm 0.3^{\mathrm{a}}$ \\
\hline Proteins & $1.1 \pm 0.1^{\mathrm{c}}$ & $1.4 \pm 0.1^{\mathrm{b}}$ & $1.3 \pm 0.0^{\mathrm{b}}$ & $2.1 \pm 0.1^{\mathrm{a}}$ \\
\hline Moisture & $67.3 \pm 3.2^{\mathrm{b}}$ & $68.6 \pm 2.2^{\mathrm{a}}$ & $64.2 \pm 2.4^{\mathrm{d}}$ & $65.9 \pm 2.7^{\mathrm{c}}$ \\
\hline
\end{tabular}

Results are expressed in wet basis. Means with different letters in the same row are significantly different from each other $(p \leq 0.05)$ according to Tukey's test.

Formulation D was observed to have significantly higher lipid and protein contents $(p \leq 0.05)$ than the other formulations. However, ash concentration was also the highest of the four samples of breads prepared with traditional flours and starches, although it was not significantly different $(p \geq 0.05)$ from formulation B. It is likely that such results are due to the presence of soybean meal in this formulation. Taghdir et al. (2016) evaluated breads produced with different soy flour concentrations $(0,5 \%, 10 \%$, and $15 \%)$ and observed that the bread samples with higher concentrations of flour also had the highest levels of ashes, lipids, and proteins. These results indicated that soybean meal can be used in gluten-free farinaceous products as an ingredient to increase nutritional quality, especially concerning mineral and protein contents in the final product. However, bread formulation A had the lowest ash content, although it did not differ statistically $(p \geq 0.05)$ from formulation C. Lipid, protein, and carbohydrate concentrations in formulation B did not differ $(p \geq 0.05)$ from those prepared in formulations A, C, and D. Gallagher et al. (2003) evaluated the chemical characteristics of seven samples of gluten-free breads added with different dairy powders, and found protein contents of $2.5 \%$ to $5.0 \%$. These values are higher than those of the four formulations of gluten-free breads prepared in the present study with traditional flours and starches (Table 4). This difference is probably due to the high protein content $(90 \%)$ of the dairy powders used by these authors.

Results of the sensory analysis of gluten-free breads made with traditional flours and starches are shown in Table 5 .

Table 5. Mean scores assigned by tasters to gluten-free breads made with traditional flours and starches.

\begin{tabular}{ccccc}
\hline Attribute & \multicolumn{3}{c}{ Formulations } \\
\cline { 2 - 5 } & $\mathbf{A}$ & $\mathbf{B}$ & $\mathbf{C}$ & $\mathbf{D}$ \\
\hline Appearance & $5.9 \pm 0.3^{\mathrm{a}}$ & $6.5 \pm 0.3^{\mathrm{a}}$ & $6.4 \pm 0.3^{\mathrm{a}}$ & $6.2 \pm 0.2^{\mathrm{a}}$ \\
\hline Aroma & $6.1 \pm 0.5^{\mathrm{a}}$ & $6.0 \pm 0.3^{\mathrm{a}}$ & $6.2 \pm 0.2^{\mathrm{a}}$ & $6.3 \pm 0.2^{\mathrm{a}}$ \\
\hline Flavor & $5.6 \pm 0.3^{\mathrm{a}}$ & $5.6 \pm 0.2^{\mathrm{a}}$ & $5.9 \pm 0.2^{\mathrm{a}}$ & $6.0 \pm 0.2^{\mathrm{a}}$ \\
\hline Texture & $5.0 \pm 0.1^{\mathrm{b}}$ & $5.5 \pm 0.2^{\mathrm{b}}$ & $5.3 \pm 0.2^{\mathrm{b}}$ & $6.4 \pm 0.2^{\mathrm{a}}$ \\
\hline Overall impression & $5.8 \pm 0.3^{\mathrm{a}}$ & $6.0 \pm 0.2^{\mathrm{a}}$ & $6.3 \pm 0.2^{\mathrm{a}}$ & $6.4 \pm 0.2^{\mathrm{a}}$ \\
\hline
\end{tabular}

Means with different letters in the same row are significantly different from each other $(p \leq 0.05)$ according to Tukey's test.

Acceptance of appearance, aroma, and flavor of bread formulations did not show significant differences $(p \geq 0.05)$. However, formulation D (with soybean meal) had higher $(p \leq 0.05)$ acceptance level concerning the texture attribute. This sample also had higher acceptance with regards to the attribute 'overall impression', 
although this difference is not statistically significant $(p \geq 0.05)$. Based on these results, formulation D (made with rice flour, soybean meal, and potato starch) was used for the preparation of gluten-free breads made with alternative flours (Table 2). Mancebo et al. (2015) optimized a combination of rice flour, maize starch, and wheat starch to produce gluten-free breads. The authors observed that the highest value for sensory acceptability was 6.50 , corresponding to the bread produced with a mixture of rice flour and wheat starch. This sensory acceptability is similar the acceptance concerning the attribute 'overall impression' (6.4) of formulation D (Table 5), made with rice flour, soybean meal, and potato starch.

Table 6 shows the chemical characteristics of breads made with alternative flours.

Table 6. Chemical compositions of gluten-free breads made with alternative flours.

\begin{tabular}{cccc}
\hline \multirow{2}{*}{ Chemical composition (\%) } & \multicolumn{3}{c}{ Formulations } \\
\cline { 2 - 4 } Carbohydrates & $\mathbf{E ~ ( 2 . 5 \% )}$ & $\mathbf{F ~ ( 5 . 0 \% )}$ & $\mathbf{G} \mathbf{( 7 . 5 \% )}$ \\
\hline Ashes & $26.3 \pm 0.5^{\mathrm{a}}$ & $29.4 \pm 0.6^{\mathrm{a}}$ & $30.9 \pm 0.6^{\mathrm{a}}$ \\
\hline Lipids & $1.8 \pm 0.1^{\mathrm{a}}$ & $1.7 \pm 0.1^{\mathrm{a}}$ & $1.5 \pm 0.1^{\mathrm{a}}$ \\
\hline Proteins & $6.9 \pm 0.3^{\mathrm{a}}$ & $6.6 \pm 0.4^{\mathrm{a}}$ & $4.2 \pm 0.3^{\mathrm{a}}$ \\
\hline Moisture & $2.1 \pm 0.1^{\mathrm{a}}$ & $2.0 \pm 0.1^{\mathrm{ab}}$ & $1.7 \pm 0.1^{\mathrm{b}}$ \\
\hline
\end{tabular}

Results are expressed in wet basis. Means with different letters in the same row are significantly different from each other $(p \leq 0.05)$ according to Tukey's test.

Carbohydrate, ashes, and lipid contents ranged from $26 \%$ to $31 \%, 1.5 \%$ to $1.8 \%$, and $4 \%$ to $7 \%$, respectively, with no significant differences $(p \geq 0.05)$ among the three formulations. Formulation $\mathrm{E}$ (with the lowest content of each alternative flours - only $2.5 \%$ ) had the highest concentrations of ashes, lipids, and proteins. The addition of alternative flours increased ash and lipid contents (Table 6) in breads, compared to formulations made with traditional flours and starches (Table 4), probably due to ash and lipid contents in PPF, PSF, and QF (Table 3). Fernandes (2006) evaluated the characteristics of whole breads with PPF $(0,3.0 \%, 6.0 \%, 9.0 \%$, and $12 \%)$ and observed that lipid contents in the samples decreased as the amount of PPF added increased. Lopes et al. (2008) evaluated the addition of PSF (0, 10\%, and 20\%) to French bread and observed that the product with the highest PSF concentration had the highest ash, lipid, protein, and fiber contents as well as the lowest caloric content. A study by Olaoye et al. (2006) showed that increasing amounts of PSF $(0,5 \%, 10 \%$, and $15 \%)$ were added to replace wheat flour in breads, lipid, protein, and ash concentrations increased in the samples. Del Castillo et al. (2009), studying the production of gluten-free bread with QF (26.32\%), found a significant difference in the nutritional composition of the formulated product compared to the commercial product without quinoa. The product developed by these authors had lower moisture content $(45.66 \mathrm{~g} / 100 \mathrm{~g})$, higher protein $(6.12 \mathrm{~g} / 100 \mathrm{~g})$ and carbohydrate contents $(39.12 \mathrm{~g} / 100 \mathrm{~g})$, and similar ash $(1.77 \mathrm{~g} / 100 \mathrm{~g})$ and lipid contents $(5.50 \mathrm{~g} / 100 \mathrm{~g})$ to the breads prepared in the present study. These differences in macronutrient contents are likely a result of the different formulations used in the preparation of the breads.

Table 7 shows results of the sensory analysis of the three formulations of gluten-free breads prepared with alternative flours.

Table 7. Mean scores assigned by tasters to gluten-free breads made from alternative flours.

\begin{tabular}{cccc}
\hline \multirow{2}{*}{ Attribute } & \multicolumn{3}{c}{ Formulations } \\
\cline { 2 - 4 } & $\mathbf{E ~ ( 2 . 5 \% )}$ & $\mathbf{F ~ ( 5 . 0 \% )}$ & $\mathbf{G ~ ( 7 . 5 \% )}$ \\
\hline Appearance & $6.0 \pm 0.2^{\mathrm{a}}$ & $6.1 \pm 0.3^{\mathrm{a}}$ & $5.8 \pm 0.2^{\mathrm{a}}$ \\
\hline Aroma & $5.6 \pm 0.1^{\mathrm{ab}}$ & $5.9 \pm 0.2^{\mathrm{a}}$ & $5.0 \pm 0.1^{\mathrm{b}}$ \\
\hline Flavor & $5.7 \pm 0.2^{\mathrm{a}}$ & $5.8 \pm 0.1^{\mathrm{a}}$ & $4.8 \pm 0.2^{\mathrm{b}}$ \\
\hline Texture & $5.8 \pm 0.2^{\mathrm{ab}}$ & $6.3 \pm 0.2^{\mathrm{a}}$ & $5.5 \pm 0.2^{\mathrm{b}}$ \\
\hline Overall impression & $5.9 \pm 0.2^{\mathrm{ab}}$ & $6.3 \pm 0.2^{\mathrm{a}}$ & $5.5 \pm 0.1^{\mathrm{b}}$
\end{tabular}

Means with different letters in the same row are significantly different from each other $(p \leq 0.05)$ according to Tukey's test. 
The mean acceptance of formulation F (5.0\% of each alternative flours) was higher than those of the other samples regarding all attributes evaluated, although with no significant difference $(p \geq 0.05)$ from sample $\mathrm{E}$. The attribute 'overall impression' of Formulation F (Table 7) was similar to that of Formulations C and D made with RF, SM, and PS, compared to results of breads made with traditional flours and starches (Table 5). Orr et al. (1982) evaluated the sensory acceptance of breads elaborated with potato peel/wheat flour blends, and observed that bread inner texture scored higher with increased $(5 \%, 10 \%$, and $15 \%)$ potato peel content in the blend. On the other hand, we observed better sensory evaluation of breads made with up to $5 \%$ potato peel flour, probably due to the effect of other added flours (pumpkin and quinoa seed) on sensory characteristics of the breads. Fernandes (2006) found that whole breads supplemented with 3.0 and $6.0 \%$ of PPF had the best performance in the sensory evaluation. Although breads with 9.0 and $12 \%$ of PPF obtained the lowest scores in the sensory evaluation, they were considered satisfactory because they had $75 \%$ of approval. Gluten-free breads elaborated by Föste et al. (2014) with $10,20,30$, and $40 \%$ of quinoa bran were evaluated regarding their sensory characteristics and had a poorer evaluation in overall acceptability than breads made in this study with PPF, PSF, and QF (Table 7), probably because of the bitter taste that quinoa bran has.

Figure 2 shows the frequency distribution of the overall impression scores and acceptability indices obtained for gluten-free breads made from either traditional or alternative flours.

(A)

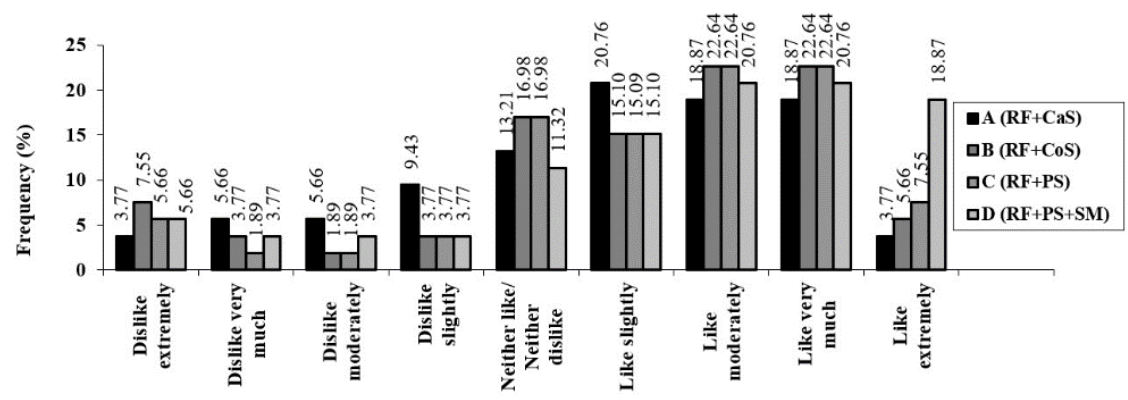

(B)

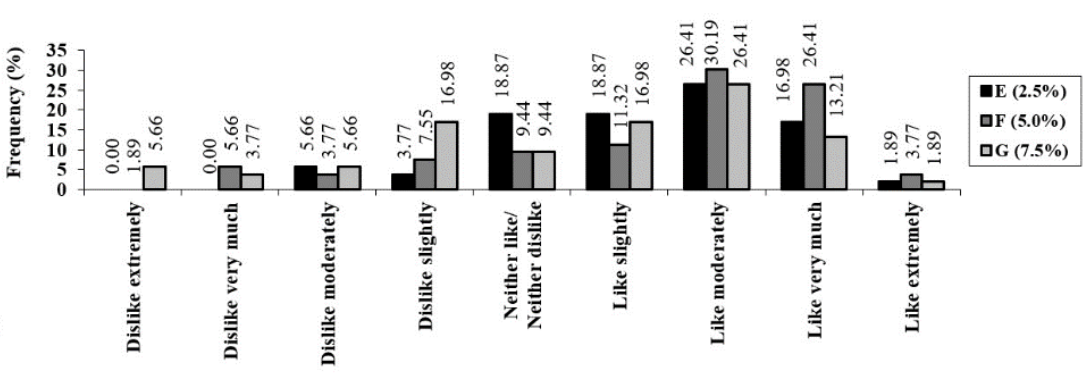

(C)

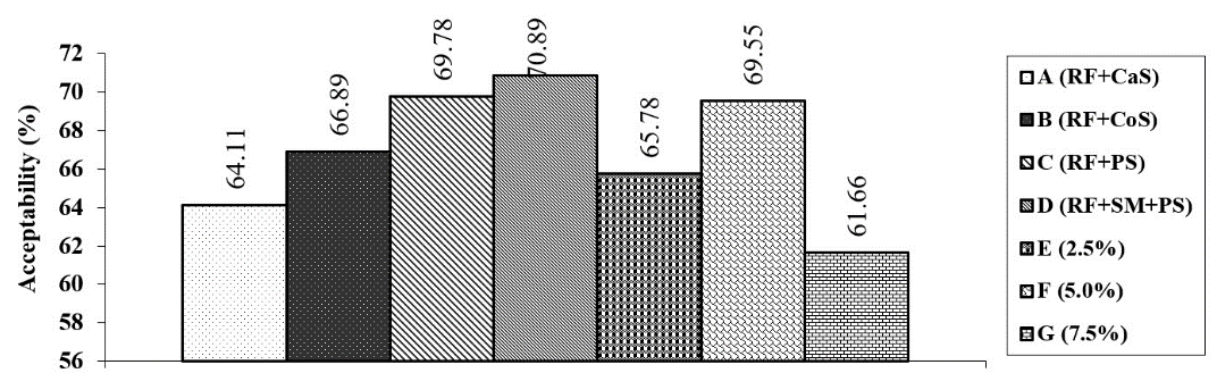

Figure 2. (A) Frequency distribution of the overall impression scores assigned by tasters to gluten-free breads made from traditional flours and starches; (B) Frequency distribution of overall impression scores assigned by tasters to gluten-free breads supplemented with alternative flours; (C) Acceptability indices of gluten-free breads made with traditional flours and starches as well as with alternative flours.

Figure 2A shows the frequency distribution of the overall impression scores obtained for gluten-free breads made from traditional flours and starches. Formulation D had the highest number of positive evaluations 
among the tasters $(75.49 \%)$. Formulation A had the highest percentage $(24.52 \%)$ of negative evaluations. Among the four formulations of gluten-free breads prepared with traditional flours and starches (Table 1), it is the only formulation with $\mathrm{CaS}$. The negative effect of $\mathrm{CaS}$ on sensory characteristics of gluten-free breads was also verified by López et al. (2004). The authors evaluated the sensory characteristics of gluten-free breads made with rice flour, $\mathrm{CoS}$ and CaS. The bread made with rice flour had the best sensory parameters regarding flavor, appearance, crumb texture, crust color, and degree of satisfaction, followed by bread made with cornstarch. The gluten-free bread made with $\mathrm{CaS}$ was the least preferred choice by the sensory evaluation panel.

Figure 2B shows the frequency distribution of the overall impression scores obtained for gluten-free breads made with alternative flours. In the three formulations, the highest frequency of positive evaluations corresponded to item "like moderately", and the highest frequency of negative evaluations corresponded to "dislike slightly". Formulation F (with 5.0\% of each alternative flours) had the highest number of positive evaluations $(71.69 \%$ ) among the tasters. Formulation G (with $7.5 \%$ of each alternative flours) had the highest percentage (32.07\%) of negative evaluations. According to Masure et al. (2016), rice flour and starches are used as the major starchy materials in most studies on gluten-free breads, although there are also numerous studies using alternative flours, alone or in combination with these starches and flours.

Acceptability indices of the seven bread samples are shown in Figure 2C. Sample D, which was used as the base formulation for supplementation with alternative flours, obtained approximately $71 \%$ of acceptability. Based on this value, this product would be commercially accepted according to DessimoniPinto et al. (2010) and Teixeira et al. (1987). Among the four formulations of gluten-free breads with traditional flours and starches (Table 1), it is the only formulation with soybean meal. The importance of soy derivatives in sensory characteristics of gluten-free breads was also observed by Taghdir et al. (2016). The authors evaluated sensory characteristics of gluten-free breads with different levels of soy flour $(0,5,10$, and $15 \%$ ) and observed that bread samples with higher concentrations of flour had the highest scores with regards to the sensory characteristics of taste, texture, color, and overall acceptability. Among the gluten-free breads prepared with alternative flours, the product supplemented with $5.0 \%$ of each alternative flours (sample F) had an acceptability index equal to $69.55 \%$, very close to $70 \%$, which is considered the minimum value for a product to be commercially accepted (Teixeira et al., 1987). This index is much higher than that of the gluten-free bread prepared with QF (26.32\%) by Del Castillo et al. (2009), which only obtained $40 \%$ acceptability. Castro et al. (2007) developed different formulations of gluten-free cakes and cookies using quinoa grains, flakes, and flour, and the products obtained acceptability levels ranging from $66.33 \%$ to $79.44 \%$.

\section{Conclusion}

The chemical and sensory results obtained showed the viability of producing gluten-free breads with PPF, PSF, and QF (5.0\% of each flour), by complementing macronutrient contents of the breads with good sensory acceptance, and therefore, providing high commercialization potential. This would also contribute to reduce waste from the food industry aside from emerging as a bread option for the portion of the population with celiac disease.

\section{References}

Ben Jeddou, K., Bouaziz, F., Zouari-Ellouzi, S., Chaari, F., Ellouz-Chaabouni, S., Ellouz-Ghorbel, R., \& Nouri-Ellouz, O. (2017). Improvement of texture and sensory properties of cakes by addition of potato peel poder with high level of dietary fiber and protein. Food Chemistry, 217, 668-677. PMid:27664685. http://dx.doi.org/10.1016/j.foodchem.2016.08.081

Brasil. Ministério da Saúde. (1996, outubro 16). Dispõe sobre diretrizes e normas regulamentadoras de pesquisas envolvendo seres humanos (Resolução $n^{\circ} 196$, de 10 de outubro de 1996). Diário Oficial da União, Brasília. 
Brasil. Ministério da Saúde. Agência Nacional de Vigilância Sanitária - ANVISA. (2005, setembro 23). Regulamento técnico para produtos de cereais, amidos, farinhas e farelos (Resolução RDC n 263, de 22 de setembro de 2005). Diário Oficial da União, Brasília.

Castro, L. I. A., Vila Real, C. M., Pires, I. S. C., Pires, C. V., Pinto, N. A. V. D., Miranda, L. S., Rosa, B. C., \& Dias, P. A. (2007) Quinoa (Chenopodium quinoa Willd): digestibilidade in vitro, desenvolvimento e análise sensorial de preparações destinadas a pacientes celíacos. Alimentos e Nutrição, 18, 413-419.

Del Castillo, V., Lescano, G., \& Armada, M. (2009). Formulación de alimentos para celíacos con base en mezclas de harinas de quínoa, cereales y almidones. Archivos Latinoamericanos de Nutrición, 59, 332-336.

Del-Vechio, G., Corrêa, A. D., Abreu, C. M. P., \& Santos, C. D. (2005). Efeito do tratamento térmico em sementes de abóboras (Curcubita spp.) sobre os níveis de fatores antinutricionais e/ou tóxicos. Ciência e Agrotecnologia, 29(2), 369-376. http://dx.doi.org/10.1590/S1413-70542005000200014

Dessimoni-Pinto, N. A. V., Silva, V. M., Batista, A. G., Vieira, G., Souza, C. R., Dumont, P. V., \& Santos, G. K. M. (2010). Características físico-químicas da amêndoa de macaúba e seu aproveitamento na elaboração de barras de cereais. Alimentos e Nutrição, 21, 77-84

Food and Agriculture Organization - FAO. (2017). Statistical database. Rome.

Fernandes, A. F. (2006). Utilização da farinha de casca de batata (Solanum tuberosum L.) na elaboração de pão integral (Dissertação de mestrado). Universidade Federal de Lavras, Lavras.

Fernandes, A. F., Pereira, J., Germani, R., \& Oiano-Neto, J. (2008). Efeito da substituição parcial da farinha de trigo por farinha de casca de batata (Solanum Tuberosum Lineu). Food Science and Technology, 28, 56-65. http://dx.doi.org/10.1590/S010120612008000500010

Föste, M., Nordlohne, S. D., Elgeti, D., Linden, M. H., Heinz, V., Jekle, M., \& Becker, T. (2014). Impact of quinoa bran on glutenfree dough and bread characteristics. European Food Research and Technology, 239(5), 767-775. http://dx.doi.org/10.1007/s00217-014-2269-x

Gallagher, E., Gormley, T. R., \& Arendt, E. K. (2003). Crust and crumb characteristics of gluten free breads. Journal of Food Engineering, 56(2-3), 153-161. http://dx.doi.org/10.1016/S0260-8774(02)00244-3

Gallagher, E., Gormley, T. R., \& Arendt, E. K. (2004). Recent advances in the formulation of glúten-free cereal-based products. Trends in Food Science \& Technology, 15(3-4), 143-152. http://dx.doi.org/10.1016/j.tifs.2003.09.012

Garmus, T. T., Bezerra, J. R. M. V., Rigo, M., \& Córdova, K. R. V. (2009). Elaboração de biscoitos com adição de farinha de casca de batata (Solanum tuberosum L.). Revista Brasileira de Tecnologia Agroindustrial, 3(2), 56-65. http://dx.doi.org/10.3895/S1981-36862009000200007

Gordillo-Bastidas, E., Díaz-Rizzolo, D. A., Roura, E., Massanés, T., \& Gomis, R. (2016). Quinoa (Chenopodium quinoa Willd), from nutritional value to potential health benefits: an integrative review. Journal of Nutrition \& Food Sciences, 6, 1-10.

Hüttner, E. K., \& Arendt, E. K. (2010). Recent advances in gluten-free baking and the current status of oats. Trends in Food Science \& Technology, 21(6), 303-312. http://dx.doi.org/10.1016/j.tifs.2010.03.005

Instituto Adolfo Lutz - IAL. (2005). Normas analíticas do Instituto Adolfo Lutz: métodos químicos e físicos para análise de alimentos (1018 p.). São Paulo.

Instituto Brasileiro de Geografia e Estatística - IBGE. (2012). Produção agrícola municipal. Rio de Janeiro.

Jha, N. K. (2015). Green design and manufacturing for sustainability (1st ed.). Boca Raton: CRC Press. http://dx.doi.org/10.1201/b19526.

Lopes, C. O., Dessimoni, G. V., Costa Da Silva, M., Vieira, G., \& Pinto, N. A. V. D. (2009). Aproveitamento, composição nutricional e antinutricional da farinha de quinoa (Chenopodium quinoa). Alimentos e Nutrição, 20, 669-675.

Lopes, M. V., Benevides, C. M. J., Lima, J. F. O., Oliveira, L. C., Silva, J. S. J., \& Rodrigues, J. R. M. (2008). Uso de farinha mista de trigo e semente de abóbora (Cucurbita spp.) na elaboração de pão francês. Higiene Alimentar, 22, 88-93.

López, A. C. B., Pereira, A. J. G., \& Junqueira, R. G. (2004). Flour mixture of rice flour, corn and cassava starch in the production of gluten-free white bread. Brazilian Archives of Biology and Technology, 47(1), 63-70. http://dx.doi.org/10.1590/S1516-89132004000100009

Ludvigsson, J. F., Leffler, D. A., Bai, J. C., Biagi, F., Fasano, A., Green, P. H. R., Hadjivassiliou, M., Kaukinen, K., Kelly, C. P., Leonard, J. N., Lundin, K. E. A., Murray, J. A., Sanders, D. S., Walker, M. M., Zingone, F., \& Ciacci, C. (2013). The Oslo definitions for coeliac disease and related terms. BMJ Journals-Gut, 62(1), 43-52. PMid:22345659.

http://dx.doi.org/10.1136/gutjnl-2011-301346

Mancebo, C. M., Merino, C., Martínez, M. M., \& Gómez, M. (2015). Mixture design of rice flour, maize starch and wheat starch for optimization of gluten free bread quality. Journal of Food Science and Technology, 52(10), 6323-6333. PMid:26396377. http://dx.doi.org/10.1007/s13197-015-1769-4

Masure, H. G., Fierens, E., \& Delcour, J. A. (2016). Current and forward looking experimental approaches in gluten-free bread making research. Journal of Cereal Science, 67, 92-111. http://dx.doi.org/10.1016/j.jcs.2015.09.009

Olaoye, O. A., Onilude, A. A., \& Idowu, O. A. (2006). Quality characteristics of bread produced from composite flours of wheat, plantain and soybeans. African Journal of Biotechnology, 5(11), 1102-1106.

Orr, P. H., Toma, R. B., Munson, S. T., \& D'Appolonia, B. (1982). Sensory evaluation of breads containing various levels of potato peel. American Potato Journal, 59(12), 605-611. http://dx.doi.org/10.1007/BF02867600 
Effect of potato peel, pumpkin seed, and quinoa flours on sensory and chemical characteristics of gluten-free breads

Jacinto, G. et al.

Paul, S. P., Johnson, J., \& Speed, H. R. (2013). Clinical update: coeliac disease in children. Community Practitioner, 86(1), 3537. PMid:23427713.

Peuckert, Y. P., Vieira, V. B., Hecktheuer, L. H. R., Marques, C. T., \& Rosa, C. S. (2010). Caracterização e aceitabilidade de barras de cereais adicionadas de proteína texturizada de soja e camu-camu (Myrciaria dúbia). Alimentos e Nutrição, 21, 147152.

Pumar, M., Freitas, M. C. J., Cerqueira, P. M., \& Santangelo, S. B. (2008). Avaliação do efeito fisiológico da farinha de semente de abóbora (Curcubita máxima, L.) no trato intestinal de ratos. Food Science and Technology, 28, 7-13. http://dx.doi.org/10.1590/S0101-20612008000500002

Pumar, M., Sampaio, C. R. P., \& Freitas, M. C. J. (2005). Estudo comparativo das abóboras baiana (Cucurbita moschata) e moranga (Cucurbita maxima): frações e composição química das farinhas de semente. In Anais do Simpósio Latino Americano de Ciência de Alimentos. Campinas: Universidade Estadual de Campinas.

Rodríguez Amado, I., Franco, D., Sánchez, M., Zapata, C., \& Vázquez, J. A. (2014). Optimization of antioxidante extraction from Solanum tuberosum potato peel waste by surface response methodology. Food Chemistry, 165, 290-299. PMid:25038678. http://dx.doi.org/10.1016/j.foodchem.2014.05.103

Sá, J. (2007). Pesquisa revela um dos alimentos mais ricos em fibras (Boletim Olhar Vital). Rio de Janeiro: Universidade Federal do Rio de Janeiro.

Scheuer, P. M., Francisco, A., Miranda, M. Z., \& Limberger, V. M. (2011). Trigo: características e utilização na panificaçãoreview. Revista Brasileira de Produtos Agroindustriais, 13(2), 211-222. http://dx.doi.org/10.15871/1517-8595/rbpa.v13n2p211222

Silvester, J., \& Duerksen, D. (2013). Celiac disease. Canadian Medical Association Journal, 185(1), 60. PMid:22872764. http://dx.doi.org/10.1503/cmaj.111646

Singh, P., Arora, A., Strand, T. A., Leffler, D. A., Catassi, C., Green, P. H., Kelly, C. P., Ahuja, V., \& Makharia, G. K. (2018). Global prevalence of celiac disease: systematic review and meta-analysis. Clinical Gastroenterology and Hepatology, 16(6), 823-836.e2. PMid:29551598. http://dx.doi.org/10.1016/j.cgh.2017.06.037

Souza, A. M., Pereira, R. A., Yokoo, E. M., Levy, R. B., \& Sichieri, R. (2013). Alimentos mais consumidos no Brasil: Inquérito Nacional de Alimentação 2008-2009. Revista de Saúde Pública, 47(Suppl. 1), 190S-199S. http://dx.doi.org/10.1590/S003489102013000700005

Taghdir, M., Mazloomi, S. M., Honar, N., Sepandi, M., Ashourpour, M., \& Salehi, M. (2016). Effect of soy flour on nutritional, physicochemical, and sensory characteristics of gluten-free bread. Food Science \& Nutrition, 5(3), 439-445. PMid:28572928. http://dx.doi.org/10.1002/fsn3.411

Teixeira, E., Meinert, E. M., \& Barbetta, P. A. (1987). Análise sensorial de alimentos (180 p.). Florianópolis: Editora da UFSC.

Thejasri, V., Hymavathi, T. V., Roberts, T. P. P., Anusha, B., \& Devi, S. S. (2017). Sensory, physico-chemical and nutritional properties of gluten free biscuits formulated with quinoa (Chenopodium quinoa Willd.), foxtail millet (Setaria italica) and hydrocolloids. International Journal of Current Microbiology and Applied Sciences, 6(8), 1710-1721. http://dx.doi.org/10.20546/ijcmas.2017.608.205

Wang, K., Lu, F., Li, Z., Zhao, L., \& Han, C. (2017). Recent developments in gluten-free bread baking approaches: a review. Food Science and Technology, 37(Suppl. 1), 1-9. http://dx.doi.org/10.1590/1678-457x.01417

Ziglio, B. R., Bezerra, J. R. M. V., Branco, I. G., Bastos, R., \& Rigo, M. (2007). Elaboração de pães com adição de farinha de sabugo de milho. Revista Ciências Exatas e Naturais, 9, 115-128.

Funding: None. 